\title{
Bone Tumors and Tumor-like lesions: A study in A Tertiary Care Hospital, Mumbai
}

\author{
Prashant Vijay Kumavat*, Nitin M Gadgil, Chetan S Chaudhari, Ujwal K Rathod, \\ Ganesh R Kshirsagar and Sangita S Margam
}

LTMMC and LTMGH Sion, Mumbai, India

\begin{abstract}
Background: Bone tumors are one of the intimidate challenge to the orthopedic surgeon. This call out for even more concern in resource poor settings, in economically developing nations. We analysed bone tumours and tumour like lesions, their demographic features like age and sex distributions, anatomical sites of occurrence and their relative frequencies,clinico-pathological characteristics and histo-morphological features as seen in a tertiary care hospital of India.

Methods: This is a retrospective study of 10 years in our department, of 216 cases of bone tumors, including primary bone tumors, metastatic lesions and tumor like lesions.

Results: A total of 216 patients were studied aged 1 to 80 years. 114 (52.78\%) patients were males and 102(47.22\%) were females. Commonest bone tumor observed in our study was metastatic tumors 40/216 cases (18.52\%).Commonest benign tumor in our study was osteochondroma $30 / 103$ cases $(29.13 \%)$ followed by giant cell tumor $27 / 103$ cases $(26.21 \%)$. Commonest Primary malignant bone tumor in our study was Ewing's tumor $11 / 48$ cases $(22.92 \%)$, followed by osteogenic sarcoma and myeloma 9 cases (18.75\%) each. Fibrous dysplasia was seen to be commonly located at jaw bone and skull region $6 / 13$ cases $(46.15 \%)$ whereas aneurysmal bone cyst was located commonly at vertebra $6 / 10$ cases $(60 \%)$. Out of 40 cases of metastatic bone tumors, 15 cases $(37.5 \%)$ showed metastasis from lung carcinoma, of which, non-small cell carcinoma made up of $80 \%$ of the cases.
\end{abstract}

Conclusion: Metastatic lesion is commonest bone tumor in our study. Commonest benign tumor was osteochondroma and giant cell tumor. Ewing's tumor is commonest primary bone tumor and fibrous dysplasia in tumor like lesions of the bone.

Keywords: Bone, Benign, Cyst, Lesions, Metastasis, Tumors.

\section{Introduction}

The evaluation and treatment of bone tumor is a crucial part of the core of orthopedics. Although tumors of bone are infrequently encountered, nonetheless, they are of great significance because some of them assume an aggressive course and prove to be more lethal, with extensive metastasis.

The wide spectrum of these tumors, their diverse origins from the multiple cell types found in bones coupled with the tendency of these tumors to produce overlapping anatomic pattern, make osseous neoplasm a complicated but highly challenging area from the point of view of morphological diagnosis. Collateral data with clinical and roentgengraphic features of these lesions are however very essential in arriving at reasonable correct diagnosis.

\section{Material and Methods}

This is retrospective study of 10 years in our department, of 216 cases of bone tumors, including primary bone tumors, metastatic lesions and tumor like lesions. The case history, roentgengraphs were collected from indoor case papers from department of radiology and orthopedics. The material from these cases was received by different methods such as open biopsy, closed biopsy, excision of tumor, or as an amputation of limb. Soft tissue was separated from bone and was processed and blocks were prepared and stained with haematoxylin and eosin stain. The lesions have been classified according to WHO international classification of bone tumor 2013. ${ }^{[1]}$ Decalcification was done by formal nitric acid: Formalin $5 \mathrm{ml}+$ Nitric acid $15 \mathrm{ml}+$ distilled water to $100 \mathrm{ml}$.

\section{Result}

Benign tumors were seen predominantly in second and third decade in our study 43 cases $(41.75 \%)$ and 27 cases $(26.21 \%)$ respectively. Male: female ratio was nearly 0.9:1 in our study (Table 1).

Primary malignant bone tumors were seen predominantly in the second decade with 11 cases $(22.92 \%)$ followed by third, fifth, and six decade with 7 cases (14.58\%) in each decade. The male: female ratio in malignant lesion is $1.8: 1$, thus affecting males predominantly. Metastatic bone 
tumors were seen in the $5^{\text {th }}$ and $6^{\text {th }}$ decade predominantly $30 \%$ and $27.5 \%$ respectively. The male: female ratio is 1.6:1(Table 1).

Tumor like lesions were seen predominantly in the second and third decade with 12 cases (48\%) and 7 cases $(28 \%)$ respectively. The male: female ratio in these tumors is 0.4 : 1 thus affecting predominantly females (Table 1).

Commonest bone tumor observed in our study were metastatic tumors 40/216 cases (18.52\%) followed by osteochondroma 30 cases $(13.89 \%)$ and giant cell tumor 27 cases $(12.5 \%)$ as shown in table 2 . Commonest benign tumor in our study was osteochondroma 30 cases (13.89\%) followed by giant cell tumor 27 cases (12.5\%) and osteoma 20 cases $(9.26 \%)$ as shown in Table 2 . Commonest primary malignant bone tumor in our study was Ewing's tumor 11 cases $(5.09 \%)$, followed by osteogenic sarcoma and myeloma both adding up 9 cases (4.16\%) each as shown in table 2.

Osteochondroma was predominantly seen in femur 12 cases $(40 \%)$. Giant cell tumor was seen predominantly at the ends of long bones of the lower extremity 15 cases $(55.56 \%)$ and osteoma was seen frequently in the skull and face bones 15 cases $(75 \%)$ as shown in Figure 1 (column chart) . Commonest site for the involvement of Ewing's tumor were tibia and femur, adding up to 8 cases $(72.73 \%)$. Osteogenic sarcoma was commonly located at femur 8 cases $(88.89 \%)$ whereas myeloma was predominantly located at vertebra 7 cases $(77.79 \%)$ as shown in Figure 1.

Fibrous dysplasia was seen to be commonly located at jaw bone and skull region 6 cases $(46.15 \%)$ whereas aneurysmal bone cyst was located commonly at vertebra 6 cases $(60 \%)$ as shown in Figure 1.

Out of 40 cases of metastatic bone tumors, 15 cases (37.5\%) showed metastasis from lung carcinoma, of which, nonsmall cell carcinoma made up of $80 \%$ of the cases. $22.5 \%$ of cases revealed metastasis from the GIT, of which 77.78 $\%$ cases were from stomach and $22.22 \%$ from the colon. We also had 4 cases $(10 \%)$ of metastasis from thyroid malignancy of which follicular carcinoma, accounted for $75 \%$ as shown in table no 3 .

\section{Discussion}

Neoplastic and tumor like conditions of bone are rare. Most patients complained of pain or swelling. Radiological features are important for the diagnosis of bone tumors. This is retrospective study of 10 years in our department, of 216 cases of bone tumors. Out of 216 cases, primary bone tumors were 151 (69.91\%), metastatic tumors were 40 cases $(18.52 \%)$ and tumor like conditions were 25 cases $(11.58 \%)$.
Chondrogenic tumors -We had 39 cases (18.06\%) of chondrogenic tumors. Osteochondroma was the commonest benign tumor 30 cases (13.89\%) and chondrosarcoma 5 cases $(2.31 \%)$ was the commonest malignant tumor. Out of 11,087 cases of bone tumors analyzed by Unni, $21.83 \%$ were chondrogenic tumors, osteochondroma was $8.9 \%$ and chondrosarcoma was $6.9 \%$. ${ }^{[2]}$

Benign cartilaginous tumors: We had 30 cases (13.89\%) of osteochondroma, commonly seen in $2^{\text {nd }}$ decade- 17 cases $(56.67 \%)$ with male predominance. Femur was the commonest site 12 cases (40\%). In a study by Bamanikar showed osteochondroma is commonest lesion in $2^{\text {nd }}$ decade with male predominance. All the cases radiologically showed a pedunculated growth arising from the metaphysis of long bones (Figure 2 a). External surface shows lobulated cartilage cap covered by fibrous membrane that is continuous with periostium covering the stalk (Figure $2 b$ ). Histologically, reveals that cartilage cap is composed of moderately cellular hyaline cartilage. At the junction with underlying cancellous, bone cartilage shows enchondral ossification.

We had 3 cases $(1.39 \%)$ chondroma, predominantly seen in $2^{\text {nd }}, 3^{\text {rd }}$ and $4^{\text {th }}$ decade, male predominance with hand and foot were the common sites similar to Davies study. ${ }^{[4]}$ Histology, revealed mature cartilage, with lobular architecture. Individual lobules were separated by thin fibrovascular septa.

Chondroblastoma is classified according to latest WHO classification as Intermediate grade (rarely metastasizing) tumor. ${ }^{[1]}$ It is an aggressive tumours which destroy the cortex and grow into the soft tissues. Recurrences may occur in the bone or adjacent soft tissue. Rare cases of chondroblastoma metastasizing to the lungs after 34 years were also reported. ${ }^{[5]}$ We had 1 case of chondroblastoma located at lower end of the femur in a 17 years old male patient finding similar to Kyriakos ${ }^{[5]}$ Histology revealed spindle cells, giant cells and immature cartilage matrix (Figure 2c).

Malignant Cartilaginous Tumours: Chondrosarcoma is the most common primary malignant bone tumour in the age group of 40-60 years. It commonly involves pelvis, femur, ribs, shoulder girdle, and vertebra with male predilection similar to other study. ${ }^{[6,7,8]}$ We had 5 case $(2.31 \%)$ of conventional chondrosarcoma. Rib was commonest site with 2 cases in ours study. CT scan taken of the rib, revealed speckled calcification which is hallmark of these tumours (Figure 2d). In most of the cases double nucleated cells, moderate atypia and lobulated appearance was seen (Figure 2e). Thus, grade II chondrosarcoma, was seen our cases. 
Table 1: Age and Sex distribution of benign, malignant, metastatic and tumor like lesions of bone.

\begin{tabular}{|c|c|c|c|c|c|c|c|c|c|c|c|}
\hline Histological lesions & $\begin{array}{l}\text { No of } \\
\text { Case } \\
(216)\end{array}$ & \multicolumn{2}{|c|}{$\begin{array}{l}\text { Sex } \\
\text { M F }\end{array}$} & $\begin{array}{l}1-10 \\
(\%)\end{array}$ & $\begin{array}{c}11-20 \\
(\%)\end{array}$ & $\begin{array}{c}21-30 \\
(\%)\end{array}$ & $\begin{array}{c}31-40 \\
(\%)\end{array}$ & $\begin{array}{c}41-50 \\
(\%)\end{array}$ & $\begin{array}{c}51-60 \\
(\%)\end{array}$ & $\begin{array}{c}61-71 \\
(\%)\end{array}$ & $\begin{array}{c}71-80 \\
(\%)\end{array}$ \\
\hline $\begin{array}{l}\text { Benign Bone } \\
\text { Tumors }\end{array}$ & 103 & \multicolumn{2}{|c|}{5053} & $11(10.68)$ & $43(41.75)$ & $27(26.21)$ & $14(13.59)$ & $6(5.83)$ & $2(1.94)$ & - & - \\
\hline Osteochondroma & 30 & 18 & 12 & 5 & 17 & 6 & - & 2 & - & - & - \\
\hline Giant cell tumor & 27 & 7 & 20 & - & 6 & 7 & 10 & 2 & 2 & - & - \\
\hline Osteoma & 20 & 9 & 11 & 1 & 10 & 5 & 2 & 2 & - & - & - \\
\hline Osteoid Osteoma & 10 & 7 & 3 & 1 & 5 & 4 & - & - & - & - & - \\
\hline Osteoblastoma & 4 & 3 & 1 & 1 & 2 & 1 & - & - & - & - & - \\
\hline Hemangioma & 4 & 2 & 2 & 1 & 1 & 1 & 1 & - & - & - & - \\
\hline Chondroma & 3 & 2 & 1 & - & 1 & 1 & 1 & - & - & - & - \\
\hline $\begin{array}{l}\text { Metaphyseal fibrous } \\
\text { defect }\end{array}$ & 2 & 0 & 2 & 2 & - & - & - & - & -- & - & - \\
\hline Chondroblastoma & 1 & 1 & 0 & - & 1 & - & - & - & - & - & - \\
\hline Neurofibroma & 1 & 0 & 1 & - & - & 1 & - & - & - & - & \\
\hline Fibromyxoma & 1 & 1 & 0 & - & - & 1 & - & - & - & - & - \\
\hline Malignant Bone tumors & 48 & 31 & 17 & $6(12.50)$ & $11(22.92)$ & $7(14.58)$ & $4(8.33)$ & $7(14.58)$ & $7(14.58)$ & $3(6.25)$ & $3(6.25)$ \\
\hline Ewing's tumor & 11 & 8 & 3 & 4 & 5 & 1 & 1 & - & - & - & - \\
\hline Myeloma & 9 & 6 & 3 & - & - & - & - & 3 & 3 & 2 & 1 \\
\hline Osteogenicsarcoma & 9 & 7 & 2 & - & 4 & 3 & - & 2 & - & - & - \\
\hline Lymphoma & 6 & 3 & 3 & 1 & 2 & 1 & - & 1 & 1 & - & - \\
\hline Chordoma & 6 & 2 & 4 & - & - & - & 1 & 1 & 1 & 1 & 2 \\
\hline Chondrosarcoma & 5 & 4 & 1 & - & - & 1 & 2 & - & 2 & - & - \\
\hline Fibrosarcoma & 1 & 1 & 0 & - & - & 1 & - & - & - & - & - \\
\hline $\begin{array}{l}\text { Hemangio- } \\
\text { endothelioma }\end{array}$ & 1 & 0 & 1 & 1 & - & - & - & - & - & - & - \\
\hline Metastatic tumor & 40 & 25 & 15 & $1(2.5)$ & - & $4(10)$ & $6(15)$ & $12(30)$ & $11(27.5)$ & $4(10)$ & $2(5)$ \\
\hline Tumor like lesions & 25 & 8 & 18 & $4(16)$ & $12(48)$ & $7(28)$ & $1(4)$ & $1(4)$ & - & - & - \\
\hline Fibrous Dysplasia & 13 & 3 & 10 & 3 & 4 & 4 & 1 & 1 & - & - & - \\
\hline $\mathrm{ABC}$ & 10 & 5 & 5 & - & 7 & 3 & - & - & - & - & - \\
\hline Solitary bone cyst & 2 & 0 & 2 & 1 & 1 & - & - & - & - & - & - \\
\hline
\end{tabular}

Figure in parenthesis indicate percentage for table 1 and 2

M: male, F : Female

Table 2: Incidence of Primary bone tumors, Metastatic lesions and tumor like lesions according to WHO in our study. (2013).

\begin{tabular}{|l|l|l|l|l|l|}
\hline Histological lesions & No. of cases & Benign lesions & No. of cases & Malignant lesions & No of cases \\
\hline A] Primary bone tumors & $151(69.91)$ & & $100(46.69)$ & $48(22.22)$ \\
\hline 1 Chondrogenic tumors & $39(18.06)$ & $\begin{array}{l}\text { Osteochondroma } \\
\text { Chondroma } \\
\text { Chondroblastoma(intermediate } \\
\text { Grade, rarely metastasing) }\end{array}$ & $\begin{array}{l}30(13.89) \\
3(1.39) \\
1(0.46)\end{array}$ & Chondrosarcoma & $5(2.31)$ \\
\hline
\end{tabular}




\begin{tabular}{|c|c|c|c|c|c|}
\hline Histological lesions & No. of cases & Benign lesions & No. of cases & Malignant lesions & No of cases \\
\hline 2 Osteogenic tumors & $43(19.91)$ & $\begin{array}{l}\text { Osteoma } \\
\text { Osteoid Osteoma } \\
\text { Osteoblastoma (intermediate, } \\
\text { Locally aggressive) }\end{array}$ & $\begin{array}{l}20(9.26) \\
10(4.63) \\
4(1.85)\end{array}$ & Osteogenic sarcoma & $9(4.16)$ \\
\hline $\begin{array}{l}3 \text { Osteogenic giant cell } \\
\text { rich tumors }\end{array}$ & $27(12.5)$ & Giant cell tumors & $27(12.5)$ & - & - \\
\hline $\begin{array}{l}\text { 4. Hematopoietic } \\
\text { Neoplasms }\end{array}$ & $15(6.94)$ & & & $\begin{array}{l}\text { Multiple Myeloma } \\
\text { NHL }\end{array}$ & $\begin{array}{l}9(4.16) \\
6(2.78)\end{array}$ \\
\hline 5. Ewing's sarcoma & $11(5.09)$ & & & Ewing's sarcoma & $11(5.09)$ \\
\hline 6. Notochordal tumors & $6(2.78)$ & - & - & Chordoma & $6(2.77)$ \\
\hline 7. Vascular tumor & $5(2.31)$ & Hemangioma & $4(1.85)$ & Hemangioendothelioma & $1(0.46)$ \\
\hline 8. Fibro-histiocytic Tumors & $3(1.39)$ & $\begin{array}{l}\text { Metaphyseal fibrous defect } \\
\text { Fibromyxoma }\end{array}$ & $\begin{array}{l}2(0.92) \\
1(0.46)\end{array}$ & & \\
\hline 9. Fibrogenic tumor & $1(0.46)$ & & & Fibrosarcoma & $1(0.46)$ \\
\hline 10. Nerve sheath tumor & $1(0.46)$ & Neurofibroma & $1(0.46)$ & & \\
\hline B] Metastatic tumor & & & & & $40(18.52)$ \\
\hline C] Tumor like lesions & $25(11.58)$ & & & & \\
\hline 1. Fibrous dysplasia & $13(6.01)$ & & & & \\
\hline 2. ABC (locally aggressive) & $10(4.63)$ & & & & \\
\hline 3. Solitary bone cyst & $2(0.92)$ & & & & \\
\hline
\end{tabular}

Table 3: Incidence of primary lesions metastasizing to the bone in our study.

\begin{tabular}{|l|l|c|}
\hline Primary site & Histological diagnosis & No of cases \\
\hline Lung & $\begin{array}{l}\text { Adenocarcinoma 6 (40\%) } \\
\text { Squamous cell Carcinoma 6 (40\%) } \\
\text { Small cell carcinoma 3 (20\%) }\end{array}$ & $15(37.5 \%)$ \\
\hline $\begin{array}{l}\text { GIT Stomach } \\
\text { Colon }\end{array}$ & $\begin{array}{l}\text { Adenocarcinoma 7 (77.78\%) } \\
\text { Adenocarcinoma 2 (22.22\%) }\end{array}$ & $9(22.5 \%)$ \\
\hline Thyroid & $\begin{array}{l}\text { Follicular carcinoma 3 (75\%) } \\
\text { Papillary carcinoma 1 (25\%) }\end{array}$ & $4(10 \%)$ \\
\hline Breast & Adenocarcinoma 3 (100\%) & $3(7.5 \%)$ \\
\hline Prostate & Adenocarcinoma 3 (100\%) & $3(7.5 \%)$ \\
\hline Kidney & $\begin{array}{l}\text { Renal cell carcinoma 1 (50\%) } \\
\text { Urothelial carcinoma of pelvicalyceal system 1(50\%) }\end{array}$ & $2(5 \%)$ \\
\hline Ovary & Adenocarcinoma 1 (100\%) & $1(2.5 \%)$ \\
\hline Cervix & Adenocarcinoma 1 (100\%) & $1(2.5 \%)$ \\
\hline- & RMS 1(100\%) & $1(2.5 \%)$ \\
\hline- & Neuroblastoma 1 (100\%) & $1(2.5 \%)$ \\
\hline Total & & $\mathbf{4 0 ( 1 0 0 \% )}$ \\
\hline
\end{tabular}

Figure and Figure Legends

Figure 1- Incidence and localization of Benign, malignant, Metastatic and tumour like lesions of bone 


\section{Chart Title}

120

100

80

60

40

103

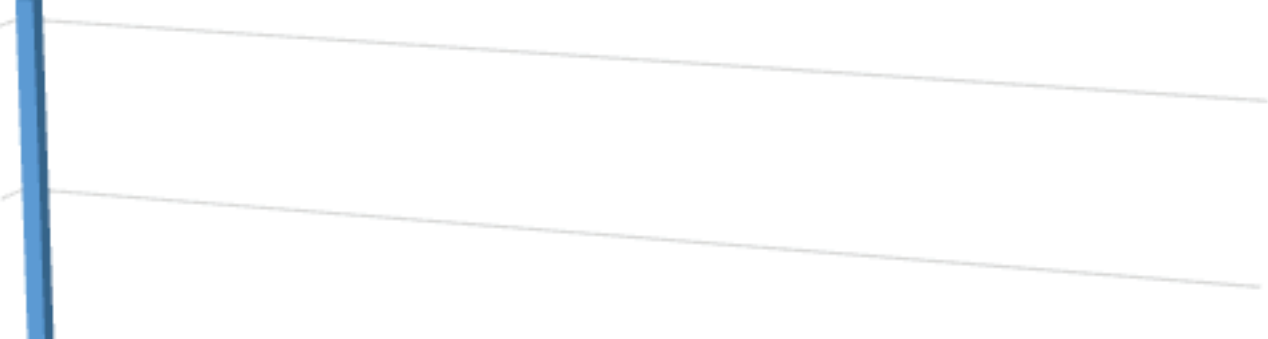

20

0

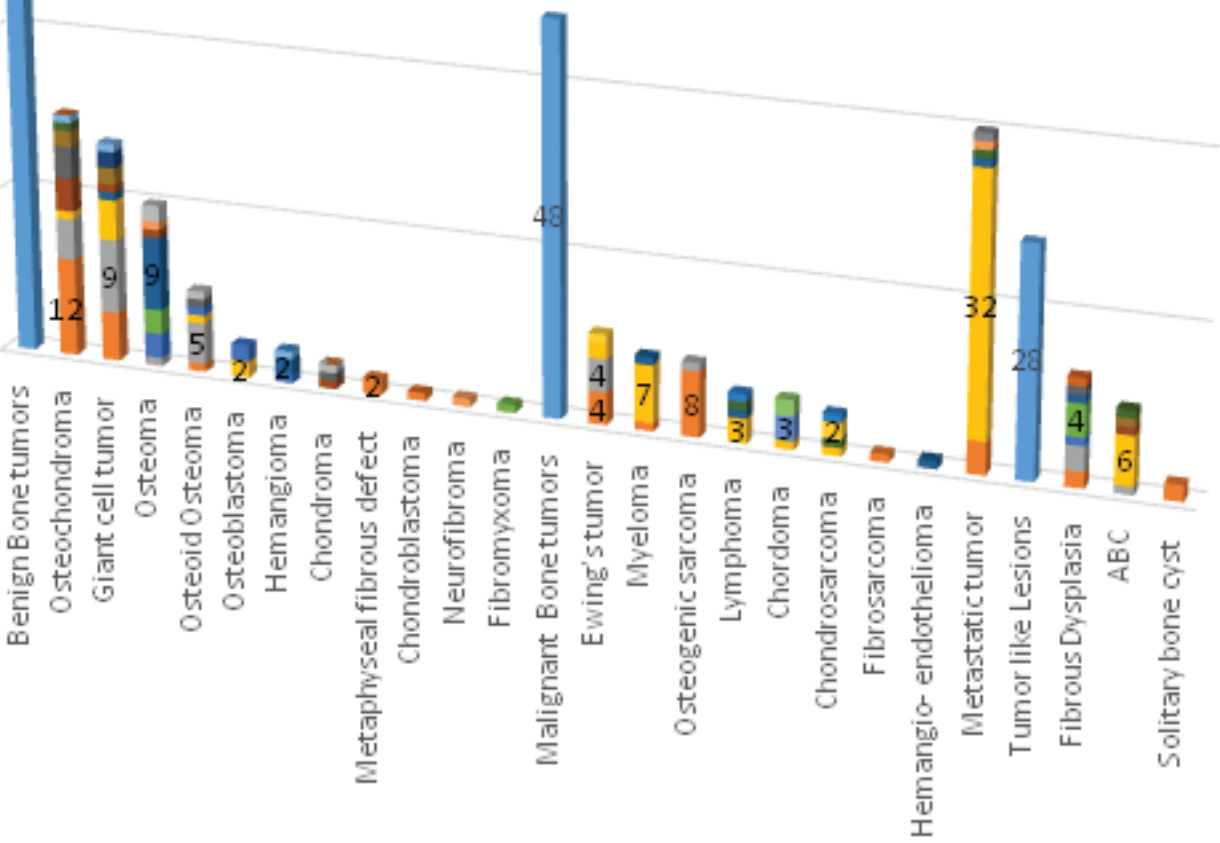

\begin{tabular}{|c|c|c|c|c|c|}
\hline No of cases 216 & a Femur & - Tibia & - Vertebra & - Face & - Mandible \\
\hline - Skull bones & - Hand & - Humerus & - Radius & - Patella & - llium \\
\hline Sacrum & Clavicle & Foot & Rib & Clivus & nasophyarynx \\
\hline - Maxilla & - Fibula & 口 Sternum & & & \\
\hline
\end{tabular}

Fig. 1: Incidence and localization of Benign, malignant, Metastatic and tumour like lesions of bone. 


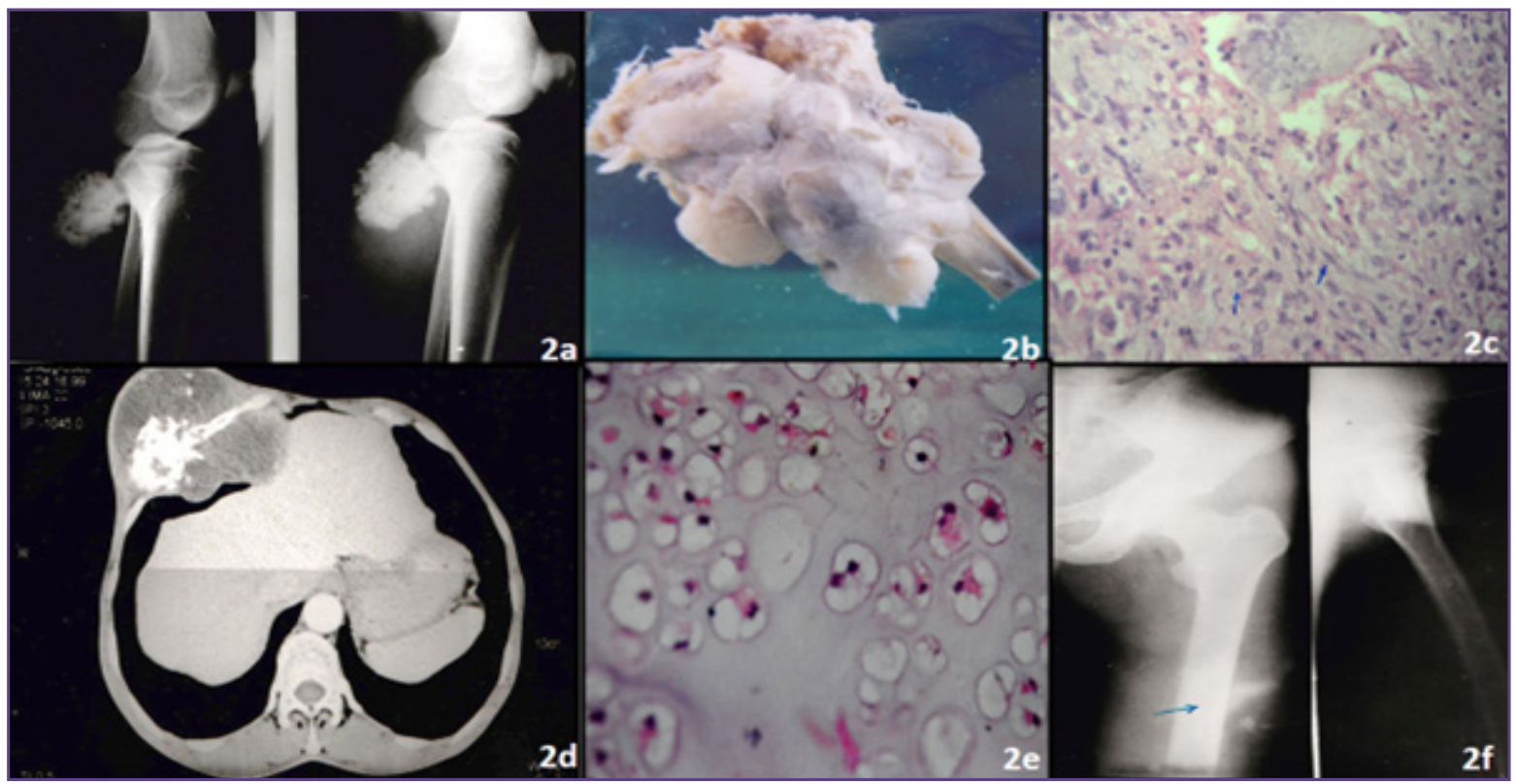

Fig. 2: 2a-Radiograph of osteochondroma, upper end of tibia showing a pedunculated growth arising from surface of the bone. 2b-Gross photograph of (2a) showing a multilobulated cartilage cap covered by fibrous membrane. 2c- Chondroblastoma showing mononuclear cells with oval nuclei showing grooving (arrow) with giant cells (H and E, 400x). 2d- Chondrosarcoma of rib, CT scan showing speckled calcification within tumour. 2e-Microscopy of $1 \mathrm{~d}$ shows nuclear crowding, binucleation and hyperchromatism (H and E, 400x). 2f- Radiograph of osteoid osteoma femur, shows radiolucent centre (nidus) surrounded by sclerotic bone (arrow).

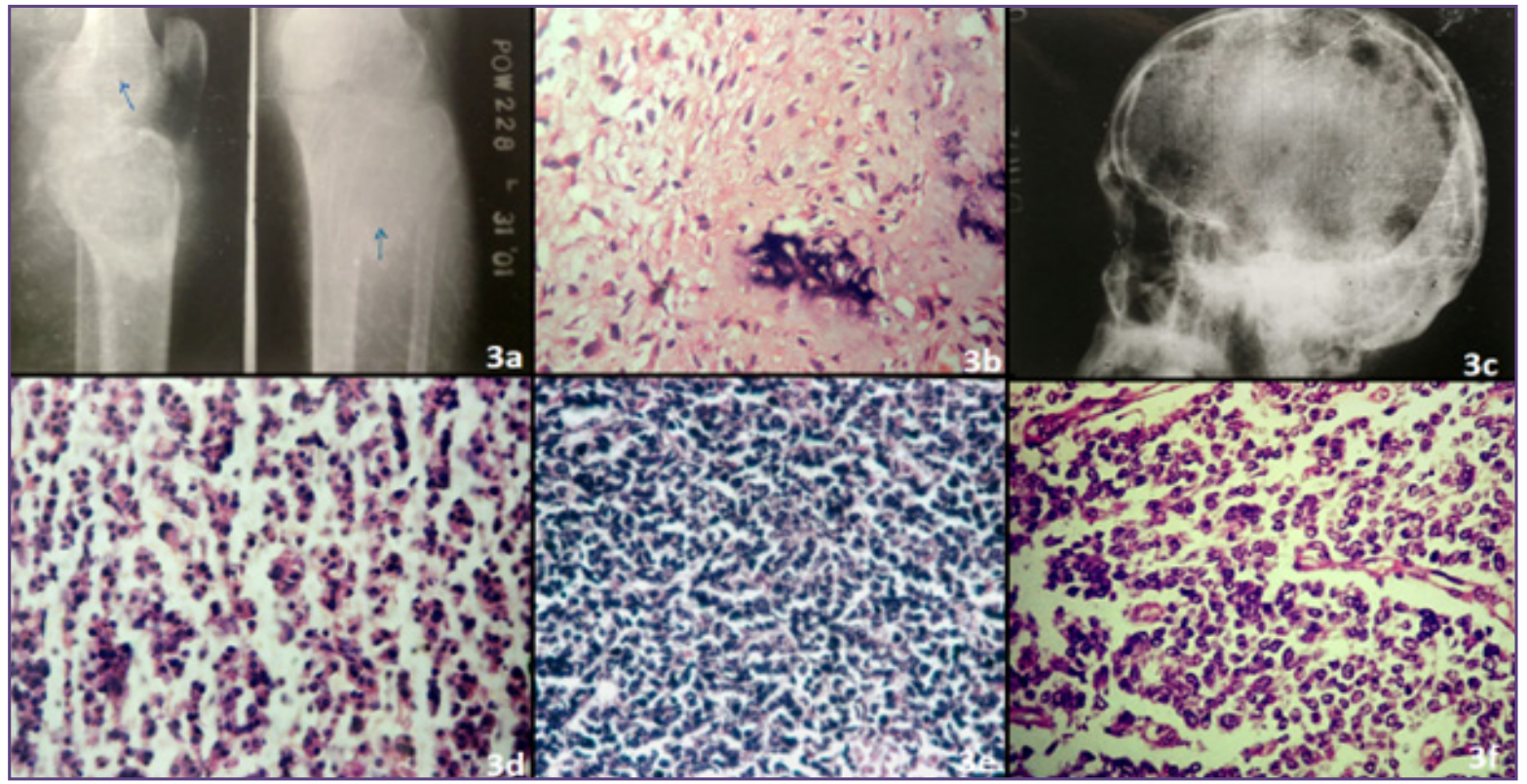

Fig. 3: 3a-Radiograph of osteogenic sarcoma knee showing an osteolytic lesion (arrow) at the lower end of femur with soft tissue extension (arrow). 3b- Osteogenic sarcoma, chondroblastic type showing chondroid differentiation, calcification and sarcomatoid area (H and E 400x). 3c- Radiograph of multiple myeloma skull showing punched out osteolytic lesions. 3dMultiple myeloma showing plasma cells with binucleation, pleomorphism and irregular hyperchromatic nuclei (H and $\mathrm{E}$ 400x). 3e- Diffuse large B cell lymphoma (H and E 400x). 3f- Ewing's tumour showing round cells arranged in pseudorosette and perivascular pattern ( $\mathrm{H}$ and $\mathrm{E}$ 400x). 


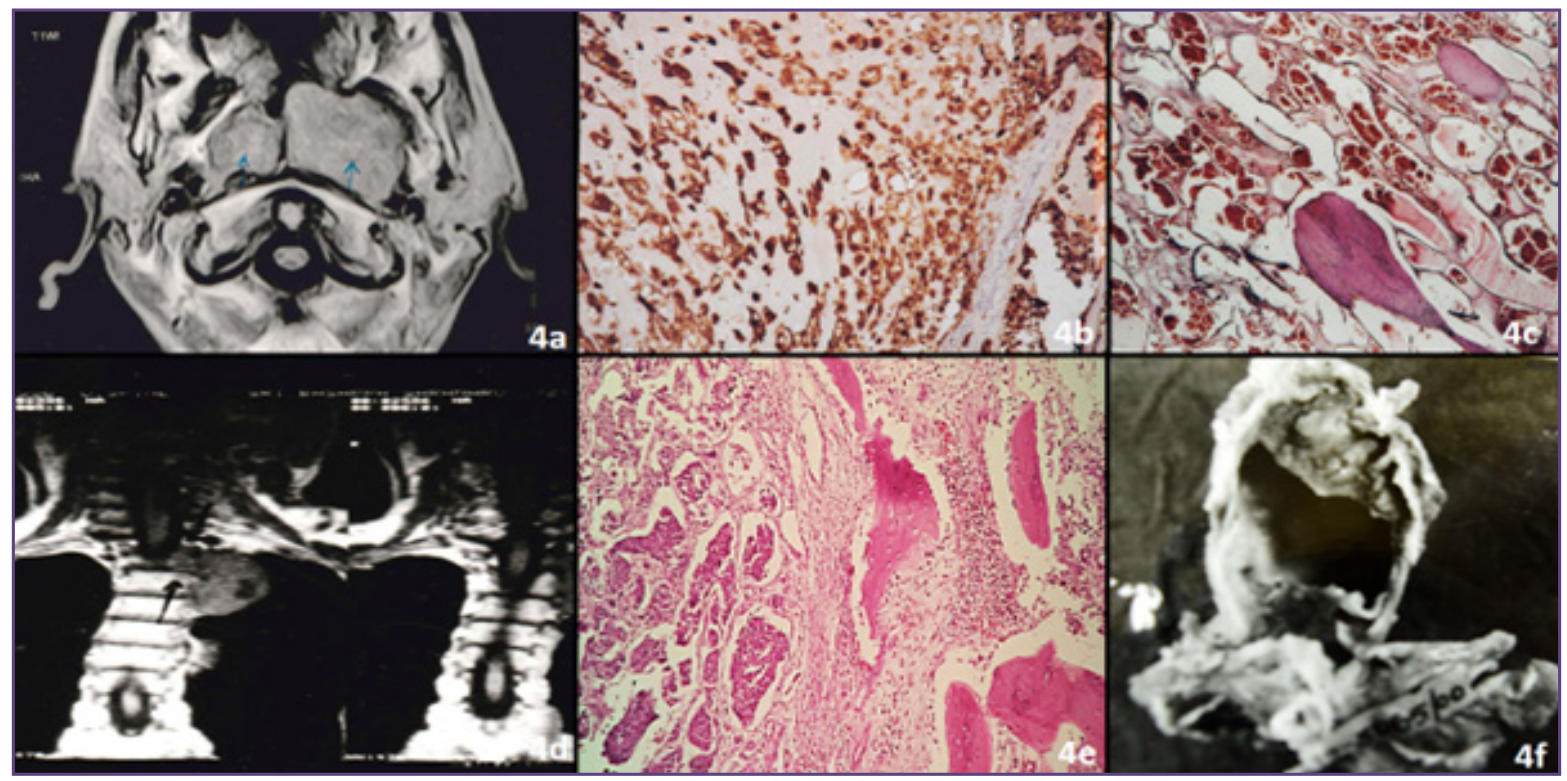

Fig. 4: 4a- CT scan of chordoma, reveals mass in nasopharynx. 4b- Chondroid chordoma showing cartilaginous areas, which are positive for S100 protein (400x). 4c- Capillary hemangioma occupying the trabecular space (H and E 400x). 4d- MRI reveals destruction of vertebra with paravertebral extension (arrow). 4e - Malignant ductual epithelium adjacent to bony trabeculae (H and E 100x). 4f- Gross photograph of aneurysmal bone cyst showing a cystic lesion with solid septal areas.

Benign Osteogenic Tumours: We had 20 cases of (9.26\%) of osteoma. Majority of them were seen in second decade with slight female predominance. Female predominance with mean age 48 years was noted by Boffano. ${ }^{[9]}$ Forty five percent of the cases involved skull bones. Histologically, revelled compact bone formation.

We had 10 cases of osteoid osteoma. Pain characteristically occurs nocturnally which responds dramatically to NSAID is characteristic symptoms, which is seen most of our cases. ${ }^{[10]}$ It was seen in the $2^{\text {nd }}$ and $3^{\text {rd }}$ decade with male predominance. Long bones of lower extremity were involved in $60 \%$ of the cases, similar findings were noted by Feletar. ${ }^{[10]} \mathrm{X}$ ray revealed well demarcated osteoblastic mass-nidus that is surrounded by sclerotic bone (Figure 2f). Histology revealed anastomosing bony trabeculae which are rimmed by osteoclast, like multinucleated giant cells.

Osteoblastoma is classified according to latest WHO classification as Intermediate grade (locally aggressive) tumour. ${ }^{[1]}$ These tumours are likely to recur, do not metastasize, and are characterized microscopically by the presence of so-called epithelioid osteoblasts. It is a rare tumour that is closely related to osteoid osteoma. It is more than $2 \mathrm{~cm}$ (osteoid osteoma less than $2 \mathrm{~cm}$ ), in diameter, commonly seen in $2^{\text {nd }}$ decade of life with male predominance. ${ }^{[10]}$ We had 4 cases $(1.85 \%)$ in $1^{\text {st }}, 2^{\text {nd }}$ and $3^{\text {rd }}$ decade with male predominance. They are equally distributed in face and vertebra.

We had 9 cases $(4.16 \%)$ of osteogenic sarcomas predominantly seen in $2^{\text {nd }}$ decade $(44.44 \%)$ with male: female ratio $3.5: 1.88 .89 \%$ of the cases were seen at the lower end of femur with similar finding to Bone,Aston and Rosenberg. ${ }^{[6,7,8]}$ We had one case, the radiology of which revealed classical features of osteogenic sarcoma with fracture of lower end of femur and another case showed osteolytic lesion at the lower end of the femur and upper end of tibia with soft tissue extension in both the cases(Figure $3 \mathrm{a}$ ). On gross examination, subperiosteal expansion, cortical destruction, tumour necrosis, haemorrhage and soft tissue invasion was seen. We had 7 cases of osteoblastic type, 1 case chondroblatic type (Figure $3 \mathrm{~b}$ ) and 1 case of periosteal sarcoma. Histology, revealed cartilage in lobules with peripheral spindling. Other fields revealed high grade sarcomatous areas.

Osteoclastic Giant Cell Rich Tumours: It is classified into benign, intermediate locally aggressive (rarely metastasizing) and malignant. We had 27 cases $(12.5 \%)$ of benign giant cell tumours (GCT) which is second commonest benign tumour similar toBamanikar study. ${ }^{[3]} \mathrm{It}$ was seen commonly in the $4^{\text {th }}(37 \%)$ and $3^{\text {rd }}(30 \%)$ decade predominantly with a male: female ratio of $0.3: 1$ results of which are similar to Bamanikar study. ${ }^{[3]}$ The commonest site involved were tibia (33.33\%) and femur (22.22\%) similar to Czerniak study. ${ }^{[1]}$ Radiologically, classical soap and bubble appearance was seen. Histology revealed moderately vascularised stroma with oval, spindle shaped mononuclear cells, uniformly interspersed with multi nucleated giant cells. The nuclei of the stromal cells were similar to the giant cells. They were found with regular outline and prominent nucleoli. 
Hematopoietic Neoplasm: We had 9 cases (4.16\%) of Multiple myelomas. Presenting sign was pain and pathological fracture. Majority of cases were seen in $6^{\text {th }}$ decade with male predominance.Commonest site of involvement was vertebra. Osteolytic lesions were seen on $\mathrm{x}$-ray (Figure 3c). Histology, revealed mature and immature plasma cells. Malignant plasma cells revealed binucleation, pleomorphism and irregular hyperchromatic nucleoli (Figure 3d). According to Greippe, the degree of immaturity of myeloma cells is prognostic factor. ${ }^{[12]}$ Moth cells, Russel bodies were also observed.

We had 6 cases $(2.78 \%)$ of primary Non-Hodgkin's lymphoma (NHL) of bone, predominantly seen in $2^{\text {nd }}$ decade with equal sex distribution. Vertebra is commonest site involved in $50 \%$ of cases. Majority of patients presented with pain and compression leading to neurological symptoms. Radiologically, NHL presents with moth eaten appearance. Grossly, tumours showed white fish flesh appearance. Diffuse large B cell lymphoma was commonest histological type (Figure 3e) which is also seen in Dosoretz study (32\%). ${ }^{[13]}$ LCA, CD 20, CD 45 and CD 3 are helpful marker in diagnosis.

Ewing'stumour Ewing's tumours (and related tumours) is a highly malignant tumour which affects diaphysis of long bones, in the $0-20$ year's age group, with male predominance. ${ }^{[7-9]}$ We had 11 cases $(5.09 \%)$ Ewing's tumour, 9 out of 11 cases were seen in age below 20 years. Incidence of Ewing's sarcoma was $4.61 \%$ in Unni. ${ }^{[2]}$ It was seen predominantly in males. It commonly involved the tibia and femur equally (36.36\%). Radiologically, femur showed a moth eaten, permeative, destructive tumour at the diaphysis with lamellar or onion skin periosteal bone reaction. Histology revealed, solid areas of uniform undifferentiated cells, with minimal amount of cytoplasm. Uniformity of nuclei, fibrous strands and blood vessels were also seen(Figure 3f). Areas of haemorrhage and necrosis was also noted. Few foci revealed peritheliomatous arrangement of cells.

Notochordal tumours We had 6 cases (2.78\%) chordoma in our study. It was seen predominantly in patients over the age of 50 years with male predominance. The commonest site involved was clivus (50\%) and nasophyarynx (33.33\%). CT scan of chordoma arising from clivus and projecting as a nasophyarynx mass was noted (Figure 4a). Histology reveals, cords or nests of solid areas of cells that have vacuolated cytoplasm embedded in myxoid intercellular matrix, with a lobular pattern. Nuclei were round or oval with prominent nucleolus.

We had one case of chondroid chordoma arising from base of the skull which presented as nasopharyngeal mass. Histology revealed, foci of cartilage along with epithelial cells. Immunohistochemistry revealed, positivity for S-100 (Figure 4b), CK, EMA, Vimentin and CEA thus chondrosarcoma was ruled out.
Fibrogenic sarcoma: We had 1 case of fibrosaroma which was seen at the lower end of femur in a 25 year old male. Multiple section taken revealed, spindle cell tumour with herring bone pattern with nuclei showing mitosis and atypia.

Vascular tumour: We had 4 cases (1.85\%) of haemangioma (Figure 4c), occurring in patients between ages of 4 to 32 years. It commonly involved the skull bones $(50 \%)$. X ray reveals lucent, well demarcated defect.

Metastatic tumour: Metastatic bone tumours occur at particularly high rates in cancers of the breast, prostate, lung, and kidney, accounting for $75 \%$ of all patients. ${ }^{[14]}$

Abrupt onset of pain is associated with pathological fracture and neurological pain were common presenting symptoms in our study. We had 40 cases $(18.52 \%)$ of metastatic tumours. They were seen predominantly in the $5^{\text {th }}(30 \%)$ and $6^{\text {th }}(27.5 \%)$ decade similar to Jain study with male predominance. ${ }^{[15]}$ Of the 40 cases of metastatic bone tumours $37.5 \%$ showed metastasis from lung carcinoma followed by $22.5 \%$ from GIT, finding of our study similar to Jain study who also reported lung carcinoma (38.46\%) metastasis to bone followed by GIT $(23.07 \%) .{ }^{[15]}$ Vertebra was the most common site involved 32 cases $(80 \%)^{[16]}$ Radiologically destruction of the vertebra was the most common finding (Figure 4d). Radiologically, destructive focus with moth eaten appearance, cortical disruption, extension into soft tissue and periosteal new bone formation may be present. ${ }^{[17]}$ Metastatic sites are usually multiple.

We had 15 known cases (37.5\%) of lung carcinoma metastasing to the bone. Of them, 12 cases $(80 \%)$ were non-small cells and $3(20 \%)$ were small cell carcinomas which is also seen in Hideshi study. ${ }^{[16]} 80 \%$ of the cases show osteolytic lesions.We had 9 (22.5\%) known cases of GIT, 7 cases were metastasis from the stomach and 2 cases were from colon. We had $3(7.5 \%)$ known case of $\mathrm{Ca}$ breast, metastasizing to the bone. One case of breast, metastasizing to upper end of femur, presented with fracture of femur neck. Histology revealed, malignant ductal epithelium adjacent to bony trabeculae (Figure 4e).

We had 3 cases (7.5\%) of prostatic Ca, histology of which showed malignant glands arranged in diffuse sheets and cribriform pattern, lying adjacent to the paratrabecular space. Prostate carcinoma with a high histologic grade (Gleason's score $\geq 7$ ), high stage, large diameter, and metastasis to pelvic lymph nodes has high chances of metastasis. ${ }^{[1]}$ We had 2 cases $(5 \%)$ of renal malignancy metastasizing to bone out of which one conventional RCC and other was being urothelial carcinoma of pelvicalyceal system. We had 4 cases of metastatic thyroid malignancy. 3 cases of follicular and one case of papillary carcinoma.

Tumor like lesions: We had 13 cases (6.01\%) of fibrous dysplasia which is commonest lesion in our study. $84.4 \%$ of the cases occurred in first three decade of life with female 
predominance. $46.1 \%$ of the cases involved facial bones in our study. Mohamad study also reveals similar features with fibrous dysplasia, being the commonest lesion with female predominance, second decade and face bones are commonly involved. ${ }^{[18]}$ Radiologically, all the cases showed osteolytic lesions. Histology revealed, immature woven bone with spindle cell proliferation.

We had 10 cases $(4.62 \%)$ aneurysmal bone cyst in our study. The patients commonly affected were in $2^{\text {nd }}(70 \%)$ and $3^{\text {rd }}(30 \%)$ decade of life with no sexual predilection. [11] Vertebra was the most common bone involved 6 cases $(60 \%){ }^{[11]}$ Radiologically blow out or ballooned distension of the periosteum outline by paper thin shell of subperiosteal bone was seen in most of the cases. ${ }^{[1]}$ Spongy or multilocular cystic lesion filled with blood is the classical gross appearance (Figure 4f). Histology, showed cystic spaces containing blood, with septa showing multinucleated giant cells and spindles cells.

\section{Conclusion}

It has become a cliché to emphasize the necessity for the close co-operation among the pathologist, radiologist and surgeon to arrive at a correct diagnosis of lesion, suspected of being a bone tumour. The pathological diagnosis is still the crucial determining factor in planning appropriate treatment.

\section{References}

1. Fletches CD, Unni KK, Mertens F, editors. World Health Organisation Classification of Tumours. Pathology and Genetics of Tumours of Soft Tissue and Bone. Lyon: 1ARC Press; 2013.

2. Unni KK. Enchondroma. Dahlin's Bone Tumours: General Aspects and Data on 11,087 Cases. Philadelphia, PA: Lippincott-Raven; 1996.

3. Bamanikar SA, Pagaro PM, Kaur P, Chandanwale SS, Bamanikar A, Buch AC. Histopathological Study of Primary Bone Tumours and Tumour-Like Lesions in a Medical Teaching Hospital. JKIMSU 2015;4(2):46-55.

4. Davies AM, Sundaram M, James SJ, editors. Imaging of bone tumours and tumour-like lesions: techniques and applications. Springer Science \& Business Media; 2009.

5. Kyriakos M, Land VJ, Penning HL, Parker SG: Metastatic chondroblastoma. Report of a fatal case with a review of the literature on atypical, aggressive, and malignant chondroblastoma. Cancer 1985;55:1770-89.
6. Bone RJ, Joints. In: Rosai J, editor. Ackerman's Surgical Pathology. St. Louis: Mosby; 1996. p. 1917-2020.

7. Aston W, Briggs T, Solomon L. Tumours. In: Solomon L, Warwick D, Nayagam S, editors. Apley's System of Orthopaedics and Fractures. 9th ed. London: Hodder Arnold, Hodder education; 2010. p. 187-224.

8. Rosenberg AE. Bones, joints and soft tissue tumours. In: Kumar V, Abbas AK, Fausto N, Aster JC, editors. Robbins and cotran; Pathologic Basis of disease. 8th ed. Gurgaon: Elsevier, Reed Elsevier India private limited; 2010. p.1205-56.

9. Boffano P, Roccia F, Campisi P, Gallesio C. Review of 43 Osteoma of the Craniomaxillofacial Region. Journal of Oral and Maxillofacial Surgery. 2012; 70(5):1093-1095.

10. Feletar M. Osteoid osteoma: a case for conservative management. Rheumatology. 2002;41(5):585-586.

11. Czerniak. Dorfman and Czerniak's Bone Tumours. Elsevier; 2016.

12. Greipp PR, Raymond NM, Kyle RA, O'Fallon WM. Multiple myeloma: significance of plasmablastic subtype in morphological classification. Blood. 1985;65(2):305-10.

13. Dosoretz DE, Raymond AK, Murphy GF, Doppke KP, Schiller AL, Wang CC, Suit HD. Primary lymphoma of bone the relationship of morphologic diversity to clinical behaviour. Cancer. 1982;50(5):1009-14.

14. Tofe AJ, Francis MD, Harvey WJ. Correlation of neoplasms with incidence and localization of skeletal metastases: An analysis of 1,355 diphosphonate bone scans. Journal of nuclear medicine: official publication, Society of Nuclear Medicine. 1975;16(11):986-989.

15. Jain K, Ravishankar R, Rupakumar CS, Gadiyar HB, Manjunath GV. Bone tumours in a tertiary care hospital of south India: a review 117 cases. Indian Journal of Medical and Paediatric Oncology. 2011;32(2):82.

16. Sugiura H, Yamada K, Sugiura T, Hida T, Mitsudomi T. Predictors of survival in patients with bone metastasis of lung cancer. Clinical orthopaedics and related research. 2008;466(3):729-36.

17. Norman A, Ulin R. A Comparative Study of Periosteal NewBone Response in Metastatic Bone Tumours (Solitary) and Primary Bone Sarcomas 1. Radiology. 1969;92(4):705-708. linical behaviour. Cancer. 1982;50(5):1009-14.

18. Mohammed A, Isa HA. Pattern of primary tumours and tumour-like lesions of bone in Zaria, Northern Nigeria. West African journal of medicine. 2007;26(1):37-41

*Corresponding author:

Dr Prashant Vijay Kumavat, room no 1303, building no 27, hawre city, kasarvadvali, Thane (w) 400615

Email:drkumavat_83@rediffmail.com

Financial or other Competing Interests: None.

Date of Submission : 17.07.2016

Date of Acceptance : 16.11.2016

Date of Publication : 04.02.2017 